\title{
Yog̃un Bakım Ünitelerinde Gram-Negatif Bakteri İnfeksiyonlarında Çoklu İlaç Direnci ve Maliyet Analizi: Retrospektif Çalıșma
}

\section{Multiple Drug Resistance and Cost Analysis in Gram-Negative Bacterial Infections in Intensive Care Units: A Retrospective Study}

\author{
Handan ALAY'(ID), Sinan YILMAZ²(ID), Fatma KESMEZ CAN'(IiD)
}

\footnotetext{
${ }^{1}$ Atatürk Üniversitesi Tıp Fakültesi, İnfeksiyon Hastalıkları ve Klinik Mikrobiyoloji Anabilim Dalı, Erzurum, Türkiye

${ }^{2}$ Atatürk Üniversitesi Tıp Fakültesi, Halk Sag̃lıg̃ı Anabilim Dalı, Erzurum, Türkiye
}

Makale atıfı: Alay H, Yılmaz S, Kesmez Can F. Yoğun bakım ünitelerinde gram-negatif bakteri infeksiyonlarında çoklu ilaç direnci ve maliyet analizi: retrospektif çalışma. FLORA 2021;26(1):142-50.

\section{ÖZ}

Giriş: Çoklu ilaç direnci (ÇiD) olan patojenlere bağlı gram-negatif bakteri infeksiyonları yoğun bakım ünitelerinde yatan hastalar için önemli morbidite ve mortalite nedenidir. Ancak, ÇiD'e sahip patojenlerin neden olduğu hastane kaynaklı infeksiyonların ekonomik maliyetleri tam olarak anlaşılamamıştır. Bu çalışmada bir üçüncü basamak hastanenin erişkin yoğun bakım ünitelerinde takip edilmiş hastalarda gelişen gram-negatif bakteri infeksiyonlarından izole edilen patojenlerde çiD görülme sıklığı ve bunlardan kaynaklanan infeksiyonların hasta bakım maliyeti ile ilişkisinin araştırılması amaçlanmıştır.

Materyal ve Metod: Atatürk Üniversitesi Tıp Fakültesi Hastanesinin yoğun bakım ünitelerinde 01.01.2016-31.03.2020 tarihleri arasında hastane infeksiyonu tanısı ile takip edilen ve çiD olan gram-negatif bakteri üremesi olan erişkin 296 hasta çalısma kapsamına alındı. Hasta bilgileri infeksiyon komitesi kayıtları üzerinden retrospektif olarak değerlendirildi. Üç ya da daha fazla antibiyotik grubundan en az birine karşı direnç tespit edilen hastalar çiD olarak kabul edildi. Hastaların ilaç, tıbbi hizmet ve antibiyotik maliyetleri hastane otomasyon sistemi kayıtlarından hesaplandı.

Bulgular: Çalışmaya 296 yoğun bakım hastası dahil edildi. Hastaların yaş ortalaması $63.9 \pm 17.0$ yıl ve \%52'si (n= 154) erkekti. Vakaların hastanede ortalama yatış süresi $34.4 \pm 30.5$ gündü. Yoğun bakımda takip edilen hastaların \%76'sı $(n=225)$ entübe ve $\% 84.8^{\prime}$ inde ( $\left.n=251\right)$ üriner kateter, \%63.5'inde $(n=188)$ santral venöz kateter, \%52.7'sinde $(n=156)$ nazogastrik sonda mevcuttu. Vakaların \%81.4'ünde ( $n=241)$ ilk epizodda saptanan patojenler ÇiD olan etkenlerdi. Yoğun bakım infeksiyonlarından en sık izole edilen patojen Acinetobacter türleri (\%56.4) iken, en nadir olarak izole edilen patojenler ise Citrobacter (\%0.7) türleri idi. Acinetobacter spp, Klebsiella spp. ve Escherichia coli'ye bağlı infeksiyonlardaki çiD varlığı anlamlı oranda yüksekti $(p<0.001)$. Çoklu ilaç direnci olan etkenlerle infekte olan hastaların toplam maliyet ortalaması 32954.4 \pm 50124.2 TL idi ve ÇiD'si bulunmayan gruptan anlamlı düzeyde yüksekti $(p=0.015)$.

Sonuç: Çoklu ilaç dirençli gram-negatif bakteri infeksiyonları hem klinik açıdan hem de ekonomik açıdan oldukça önemlidir. Çoklu ilaç direnci olan gram-negatif bakteri infeksiyonları antibiyotik maliyetini, toplam maliyetleri ve YBÜ'nde kalış süresini artırmaktadır.

Anahtar Kelimeler: Yoğun bakım; Çoklu ilaç direnci; gram-negatif; Antibiyotik; Maliyet 


\title{
ABSTRACT \\ Multiple Drug Resistance and Cost Analysis in Gram-Negative Bacterial Infections in Intensive Care Units: A Retrospective Study
}

\author{
Handan ALAY', Sinan YILMAZ², Fatma KESMEZ CAN ${ }^{1}$
}

\footnotetext{
${ }^{1}$ Department of Infectious Diseases and Clinical Microbiology, Atatürk University Faculty of Medicine, Erzurum, Turkey

${ }^{2}$ Department of Public Health, Atatürk University Faculty of Medicine, Erzurum, Turkey
}

\begin{abstract}
Introduction: Gram-negative bacterial infections, pathogens with multiple drug resistance (MDR), are an important cause of morbidity and mortality in patients admitted to intensive care units (ICUs). However, the economic costs of hospital-acquired infections caused by pathogens with MDR are uncertain. The aim of this study was to investigate the incidence of MDR in pathogens isolated from gram-negative infections developing in patients followed-up in adult intensive care units in a tertiary hospital and to examine the relation between infections deriving from these and patient care costs.
\end{abstract}

Materials and Methods: Two hundred and ninety-six adult patients diagnosed with hospital-acquired infection in the intensive care units of Ataturk University Faculty of Medicine hospital between 01.01.2016 and 31.03.2020 and with multiple drug resistant gram-negative bacteria growth were included into the study. Patient data were examined retrospectively from infection committee records. Patients with resistance in at least one out of three or more antibiotic groups were regarded as having MDR. Patients' drug, service, and antibiotic costs were calculated from the hospital automation system.

Results: Two hundred and ninety-six intensive care patients were included into the study. Patients' mean age was $63.9 \pm 17.0$ years, and $52.0 \%(n=96)$ were males. Mean length of hospital stay was $34.4 \pm 30.5$ days. Seventy-six percent $(n=225)$ of the patients followed-up in intensive care were intubated, urinary catheter was present in $84.8 \%(n=251)$, central venous catheter in $63.5 \%(n=$ $188)$, and nasogastric catheter in $52.7 \%(n=156)$. Agents identified in the first episode were multiple drug resistant in $81.4 \%$ ( $n=$ 241) of the cases. The most commonly isolated pathogen in ICU infections was Acinetobacter spp. (56.4\%), while the least frequently isolated pathogen was Citrobacter (0.7\%). A significant difference was observed between MDR distributions in Acinetobacter spp., Klebsiella spp., and Escherichia coli infections ( $p<0.001)$. The mean total cost for patients with MDR was $32954.4 \pm 50124.2$ Turkish Lira, significantly higher than in the non-MDR group $(p=0.015)$.

Conclusion: Multiple drug resistant gram-negative bacterial infections are very important both clinically and economically. Multiple drug resistant gram-negative bacterial infections increase antibiotic and total costs and length of stay in intensive care.

Key Words: Intensive care; Multiple drug resistance; gram-negative; Antibiotic; Cost

\section{GiRiș}

Günümüzde yoğun bakım ünite (YBÜ)'lerde verilen hizmetlerin niteliğinde sağlanan önemli gelișme ve ilerlemelere rağmen sepsis sıklı̆̆ artmaya devam etmektedir ${ }^{[1]}$. Dirençli patojen kaynaklı infeksiyon sıklığı YBÜ'lerde takip edilen hastalarda artmakta, bununla beraber yoğun bakımda kalma süreleri uzamaktadır ${ }^{[2]}$. Yoğun bakım hastalarında gözlenen bu infeksiyonların sıklığındaki artıștan ek hastalıklarının sayıca fazla olması ve akut fizyolojik değișimlere olan duyarlllıkları sorumlu olabilir ${ }^{[3]}$. Ayrıca, YBÜ'lerdeki hastalarda kalıcı kateterlerin varlığ1 mikroorganizmaların vücuda girișini kolaylaștırmakta, hasta bakımı esnasında nozokomiyal patojenlerle kolonizasyona ve infeksiyonlara neden olabilmektedir. Diğer taraftan bu cihazların varlığı bazı patojenler için rezervuar görevi de yapmakta ve patojenlerin hastadan hastaya horizontal geçisine zemin hazırlamaktadır ${ }^{[4]}$.

YBÜ'lerde takipleri esnasında infeksiyon gelisen hastalardan sıklikla coklu ilaç direnci (CiD) olan patojenler (Acinetobacter baumannii, Enterobacteriaceae'lar gibi) izole edilmektedir ${ }^{[5,6]}$. Bu dirençli patojenlerle olușan infeksiyonlar artmıs morbidite ve mortaliteyle birlikte hastane maliyetlerinde de artıșlara yol açmaktadır ${ }^{[7,8]}$.

Yoğun bakım ünitesi ile ilișkili infeksiyon çalıșmalarının çoğu sanayileșmiș ülkelerden cıkmaktadır. Türkiye'den hastanelerin de katıldığı cok merkezli prospektif bir calıșmanın sonuçları da YBÜ kaynaklı infeksiyonların gelismekte olan ülkelerde daha yüksek oranlarda görüldüğüinü doğrular niteliktedir ${ }^{[9]}$. Coklu ilac direnci olan patojenlerin neden olduğu yoğun bakım infeksiyonlarının 
hastanede kalma sürelerini ve mortalite oranlarını artırdığı yönünde sonuc bildiren calıșmalar mevcuttur ${ }^{[10,11]}$. Diğer taraftan bazı calıșmalarda mortalite ve hastanede kalma süresi üzerine CiD olan patojen infeksiyonlarının etkisi olmadığı gösterilmiștir ${ }^{[12,13]}$.

$\mathrm{Bu}$ çalıșmada bir üçüncü basamak hastanenin erișkin yoğun bakım ünitelerinde takip edilen hastalarda gelisen gram-negatif bakteri infeksiyonlarında CCID görülme sıklığı ve ÇID olan patojenlerle infeksiyonların hasta bakım maliyeti üzerine etkilerinin değerlendirilmesi amaçlanmıștır.

\section{MATERYAL ve METOD}

Kesitsel tipte planlanan bu calıșma il merkezinde bulunan ve 1418 yatak kapasiteli Atatürk Üniversitesi Tip Fakültesi hastanesinde yürütüldü. Atatürk Üniversitesi Tıp Fakültesi Klinik Araștırmalar Etik Kurulundan çalıșmanın etik (16.01.20/01-51) izni alındi. Hastanede toplamda 81 yatak kapasiteli anestezi, genel cerrahi, kalp damar cerrahisi, dahiliye ve beyin cerrahisi erișkin YBÜ'lerde 01.01.2016-31.03.2020 tarihleri arasında takip edilen hastalar çalıșmanın evrenini olușturmakta idi. Örneklem secimine gidilmeden ilgili tarih aralığında yoğun bakımlarda tedavi gören hastalardan sağlık bakım hizmeti ilișkili infeksiyon tanısı alan ve gram-negatif bakteri üremesi olanlar çalısmaya dahil edildi. Hasta verileri infeksiyon komitesi kayitlarından ve hastane otomasyon sisteminden sağlandı. Calıșmanın bağımlı değișkenleri ÇID sıklığı ve hasta bakım maliyeti idi. Bağımsız değișkenleri ise hastaya ait demografik veriler ve hastalarda invaziv girișim bulunma durumları idi.

Takip edilen hastalarda yatıstan 48 saat sonra ortaya çkan infeksiyonlar sağlık hizmeti ilișkili olarak değerlendirildi. Farklı infeksiyon tanımlamalarında Hastalık Kontrol ve Önleme Merkezi tanı kriterleri uygulandi ${ }^{[14]}$.

Hastalardan izole edilen etkenlerin üc veya daha fazla antibiyotik grubundan en az birine dirençli olması durumu ÇID olarak tanımlandi ${ }^{[15]}$

Calıșma kapsamındaki her hasta için hastane otomasyon sisteminden sağlanan veriler ile ilaç, hizmet, antibiyotik ve tibbi giderler hesaplanarak toplam maliyetler değerlendirildi. Hesaplamada doğrudan ve sağlık hizmeti ilișkili kalemler dikkate alındı.
Verilerin analizinde Statistical Package for the Social Sciences (SPSS v20.0) programı kullanıld1. Kategorik değișkenler sayı ve yüzde, rakamsal değiskenler ise ortalama, standart sapma, ortanca, minimum ve maksimum değerler olarak sunuldu. Rakamsal değișkenlerin normal dağılıma uygunluğu Kolmorov Smirnov testi, carpıklık ve basılklk için hesaplanan $\mathrm{z}$ değerleri, ayrıca grafikleme yöntemleri ile araștırıldı. Normal dağılmayan rakamsal değișkenler için bağımsız gruplar arası karșılaștırmalarda Kruskal-Wallis, Mann Whitney U, post-hoc analizlerde Bonferroni düzeltmeli Mann Whitney U testleri, kategorik değișkenlerin karșlaștırılmasında ise $\chi^{2}$ testi kullanıldı. Analizlerde istatistiksel anlamlilık düzeyi $\mathrm{p}<0.05$ olarak kabul edildi.

\section{BULGULAR}

Calıșmaya ilk infeksiyon epizodunda gram-negatif patojen izole edilen 296 yoğun bakım hastası dahil edildi. Hastaların yas ortalaması 63.9 \pm 17.0 yil ve \%52.0'si ( $n=154)$ erkekti. Yoğun bakım hastalarının yas ve cinsiyet dağılımları ÇID olan patojen infeksiyonu bulunma durumuna göre benzerdi ( $p>0.05$ ).

Yoğun bakımlarda takip edilen hastaların ortalama yatıs süresi $34.4 \pm 30.5$ gün olup; bu süre nöroloji hastalarında en uzun (53.5 \pm 44.3 gün) ve dahiliye hastalarında ise en kısa (21.5 \pm 19.4 gün) olarak saptand. Cíd (+) ve ÇID (-) patojenlere bağlı infeksiyonu olan hastaların yatıs süresi dağılımları benzerdi ( $p>0.05$ ).

Hastaların buiyük çoğunluğu anestezi (\%25.7) ve genel cerrahi (\%23.3) YBÜ'lerde takip edilmiști. Beyin cerrahi ve kalp damar cerrahisi YBÜ'ler haric, diğer YBÜ'lerde takip edilen hastalarda CiID (+) patojenlere bağlı infeksiyon sıklığı CíD (-) patojenlere bağlı infeksiyon sıklığından daha yüksek ve dağılımlar arasında anlamlı fark vardı $(p<0.001)$.

Vakalarda hem CiD (+) hem de Cíd (-) patojenlere bağlı olarak en sık gözlenen infeksiyon ventilatör ilișkili pnömoni (VIP) (sırasıyla \%33.3 ve \%30.0) iken, en az gözlenen ise organ bosluk infeksiyonu (\%2.1) idi. VIP, kateter ilișkili kan dolașımı infeksiyonu, bakteriyemi ve yüzeyel cerrahi alan infeksiyonlarından izole edilen ÇID (+) patojen sıklığı, ÇID (-) patojen sıklığından yüksekti (Tablo 1). 
Tablo 1. Hastaların demografik özellikleri, yatış süresi, yoğun bakım ünitesi, infeksiyon türü, izole edilen patojen ve prognoza göre çoklu ilaç direnci (ÇiD) olma durumlarının dağılımı

\begin{tabular}{|c|c|c|c|c|}
\hline & $\begin{array}{c}\text { Genel } \\
(n=296)\end{array}$ & $\begin{array}{c}\text { ÇiD (+) } \\
(n=241)\end{array}$ & $\begin{array}{l}\text { ÇiD (-) } \\
(n=55)\end{array}$ & $\mathbf{p}$ \\
\hline \multicolumn{5}{|l|}{ Yaş } \\
\hline Ortalama (SD) & $63.9 \pm 17.0$ & $63.9 \pm 17.2$ & $64.0 \pm 16.2$ & \\
\hline Ortanca (IQR) & $68.0(54.0-78.0)$ & $68.0(52.0-78.0)$ & $67.0(54.0-77.0)$ & $>0.05$ \\
\hline \multicolumn{5}{|l|}{ Cinsiyet } \\
\hline Kadın & $142(48.0)$ & $116(48.1)$ & $26(47.3)$ & $>0.05$ \\
\hline Erkek & $154(52.0)$ & $125(51.9)$ & $29(52.7)$ & \\
\hline \multicolumn{5}{|l|}{ Yatış Süresi } \\
\hline Ortalama (SD) & $34.4 \pm 30.5$ & $35.1 \pm 30.9$ & $31.1 \pm 28.8$ & \\
\hline Ortanca (IQR) & $27.0(15.0-41.0)$ & $28.0(16.0-41.0)$ & $25.0(12.0-39.0)$ & $>0.05$ \\
\hline \multicolumn{5}{|l|}{ Yoğun Bakım Ünitesi } \\
\hline Anestezi & $76(25.7)$ & $66(27.4)$ & $10(18.2)$ & $<0.001$ \\
\hline Genel Cerrahi & $69(23.3)$ & $59(24.5)$ & $10(18.2)$ & $<0.001$ \\
\hline Nöroloji & $54(18.2)$ & $45(18.7)$ & $9(16.4)$ & $<0.001$ \\
\hline Dahiliye & $41(13.9)$ & $34(14.1)$ & $7(12.7)$ & $<0.001$ \\
\hline Beyin Cerrahi & $37(12.5)$ & $28(11.6)$ & $9(16.4)$ & 0.002 \\
\hline Kalp Damar Cerrahisi & $19(6.4)$ & $9(3.7)$ & $10(18.2)$ & $>0.05$ \\
\hline \multicolumn{5}{|l|}{ İnfeksiyon Türü } \\
\hline Ventilatör ilişkili pnömoni & $97(32.8)$ & $83(34.4)$ & $14(25.5)$ & $<0.001$ \\
\hline Kan dolaşımı infeksiyonu & $82(27.7)$ & $75(31.1)$ & $7(12.7)$ & $<0.001$ \\
\hline Üriner sistem infeksiyonu & $33(11.1)$ & $22(9.1)$ & $11(20.0)$ & $>0.05$ \\
\hline Yüzeyel cerrahi alan infeksiyonu & $30(10.1)$ & $23(9.5)$ & $7(12.7)$ & 0.003 \\
\hline Derin cerrahi alan infeksiyonu & $24(8.1)$ & $16(6.6)$ & $8(15.4)$ & $>0.05$ \\
\hline Bakteriyemi & $16(5.4)$ & $12(5.0)$ & $4(7.3)$ & 0.046 \\
\hline İntrakranial infeksiyon & $8(2.7)$ & $5(2.1)$ & $3(5.5)$ & \\
\hline Organ boşluk infeksiyonu & $6(2.1)$ & $5(2.1)$ & $1(1.8)$ & \\
\hline \multicolumn{5}{|l|}{ Hastalardan İzole Edilen Patojenler } \\
\hline Acinetobacter spp. & $148(56.4)$ & $136(60.7)$ & $12(21.8)$ & $<0.001$ \\
\hline Klebsiella spp. & $66(22.3)$ & $50(20.7)$ & $16(29.1)$ & $<0.001$ \\
\hline E. coli & $51(17.2)$ & $37(15.4)$ & $14(25.5)$ & 0.001 \\
\hline P. aeruginosa & $18(6.1)$ & $11(4.6)$ & $7(12.7)$ & $>0.05$ \\
\hline Enterobacter cloacae & $8(2.7)$ & $5(2.1)$ & $3(5.5)$ & \\
\hline Proteus spp. & $3(1.0)$ & $2(0.8)$ & $1(1.8)$ & \\
\hline Citrobacter spp. & $2(0.7)$ & -- & $2(3.6)$ & \\
\hline \multicolumn{5}{|l|}{ Prognoz } \\
\hline Ölüm & $194(65.5)$ & $160(66.4)$ & $34(61.8)$ & $>0.05$ \\
\hline Sağ kalım & $102(34.5)$ & $81(33.6)$ & $21(38.2)$ & \\
\hline
\end{tabular}

Yoğun bakım infeksiyonlarından en sı izole edilen patojen Acinetobacter türleri (\%50.0) iken, en nadir olarak izole edilen patojen ise Citrobacter spp. (\%0.7) idi. Acinetobacter spp., Klebsiella spp. ve E. coli suslarında CiD oranları arasinda anlamlı fark vardı $(\mathrm{p}<0.001)$. Yoğun bakımlarda takip edilen hastaların \%65.5'i hayatını kaybetmisti. Yașayan ve hayatını kaybeden hastalardan izole edilen etkenlerin CiD oranları benzerdi ( $p>0.05$ ). Hastaların demografik özellikleri, yatıs süresi, yo- ğun bakım ünitesi, infeksiyon türü, izole edilen patojen ve prognoza göre etken patojenlerin CiD durumlarının dağılımı Tablo 1'de sunuldu.

Yoğun bakım hastalarında invaziv girișim olarak \%84.8 ile en sik üriner kateter, en nadir olarak ise \%1.4 ile endoskopik retrograt kolanjiopankreatografi (ERCP) uygulaması göze carpmakta idi. Bunun yanında hastaların \%76.0'sı entübe olarak takip edilmis ve \%63.5'inde santral venöz 
Tablo 2. Hastalara uygulanan invaziv girişimlerin dağılımı

\begin{tabular}{lcc} 
İnvaziv Girişimler & $\mathbf{n}$ & $\%$ \\
\hline Üriner kateter & 251 & 84.8 \\
Entübasyon & 225 & 76.0 \\
Mekanik Ventilasyon & 224 & 75.7 \\
SVK$^{*}$ & 188 & 63.5 \\
NGS $^{\#}$ & 156 & 52.7 \\
Diren & 87 & 29.4 \\
PVK $^{£}$ & 82 & 27.7 \\
Trakeotomi & 57 & 19.3 \\
Kolostomi & 20 & 6.8 \\
TPN\& & 15 & 5.1 \\
Göğüs tüpü & 7 & 2.4 \\
ERCP & 4 & 1.4 \\
\hline
\end{tabular}

${ }^{\#}$ NGS: Nazogastrik sonda, *SVK: Santral venöz kateter, ${ }^{£}$ PVK: Periferik venöz kateter, ${ }^{\circledR}$ TPN: Total parenteral nutrisyon, ERCP: Endoskopik retrograd kolanjio pankreatografi.

kateter kullanılmıștı. Hastalara uygulanan invaziv girișimlerin dağılımı Tablo 2'de sunuldu.

Yoğun bakım hastalarının toplam maliyet ortalaması $30665.9 \pm 19398.7$ TL idi. Hastaların takip edildikleri üniteye göre maliyetlerine bak1dığında; nöroloji hastalarının $42346.1 \pm 31409$ TL ile en yüksek, kalp damar cerrahisi hastalarının ise $16546.0 \pm 23872.8 \mathrm{TL}$ ile en düsük maliyet ortalamasına sahip olduğu görüldü. Kalp damar cerrahisi ile anestezi ve nöroloji, dahiliye ile anestezi ve nöroloji, genel cerrahi ile anestezi ve nöroloji yoğun bakım ünitelerinde takip edilen hastaların maliyet dağılımları arasında anlamlı düzeyde fark bulundu $(\mathrm{p}<0.001)$.

Hastalarda saptanan infeksiyon türlerine göre toplam hasta maliyetleri incelendiğinde; kateter ilișkili kan dolașımı infeksiyonu olan hastalarda maliyet ortalaması $42593.7 \pm 75381.6$ TL ile en yüksek iken, derin insizyonel cerrahi alan infeksiyonu olan hastalarda ise $12438.8 \pm 13230.5 \mathrm{TL}$ ile en düșüktü. Hastalardan derin insizyonel cerrahi alan infeksiyonu olanlar ile üriner sistem infeksiyonu ve kateter ilișkili kan dolașımı infeksiyonu olanların toplam maliyet dağılımları arasında anlamlı düzeyde fark vardı $(p<0.001)$. Diğer yandan ventilatör iliskili pnömonisi olan hastalar ile derin insizyonel cerrahi alan infeksiyonu ve yüzeyel cerrahi alan infeksiyonu olan hastaların maliyet dağılımları da anlamlı düzeyde farkllık göstermekteydi $(\mathrm{p}<0.001)$.
Yoğun bakım hastalarının infeksiyonlarından izole edilen patojenlere göre toplam maliyetler değerlendirildiğinde ise; Acinetobacter spp. infeksiyonlarında toplam maliyet ortalaması $38911.0 \pm$ 60421.6 TL ile en yüksek iken, E. coli infeksiyonlarında $14055.7 \pm 11158.0 \mathrm{TL}$ ile en düșük olduğu görüldü. Vaka sayısı yetersiz olan Citrobacter spp. ve Proteus spp. kaynakl infeksiyonlar haric tutulduğunda, izole edilen patojen türlerine göre hastaların toplam maliyet dağılımları arasında anlaml düzeyde fark bulundu $(\mathrm{p}<0.001)$. E. coli infeksiyonu bulunanlar ile Klebsiella spp. ve Acinetobacter spp. infeksiyonu bulunan hastaların maliyet dağılımlarının anlamlı düzeyde farklı olduğu saptandı $(p<0.001)$.

Yoğun bakım hastalarının infeksiyonlarından izole edilen etkenlerin CiD olmasına göre maliyetler incelendiğinde; CiD bulunan grupta toplam maliyet ortalamasının $32954.4 \pm 50124.2 \mathrm{TL}$ ile CiD bulunmayan gruptan anlaml düzeyde yüksek olduğu saptandı $(p=0.015)$. Hasta maliyetlerinin yoğun bakım ünitesi, infeksiyon türü, izole edilen patojenler ve etkenin CíD olmasına göre dağılımlar1 Tablo 3'te sunuldu.

\section{TARTIȘMA}

Çoklu ilaç dirençli gram-negatif bakterilerle olușan infeksiyonlar tüm dünyada ve ülkemizde giderek artmakta olan önemli bir sorundur. Amerika Infeksiyon Hastalıkları Derneği genișlemis 
Tablo 3. Yoğun bakım ünitesi, infeksiyon türü, patojen ve patojenlerin çoklu ilaç direnci olma durumlarına göre maliyet dağılımları

\begin{tabular}{|c|c|c|c|c|}
\hline & \multicolumn{4}{|c|}{ Maliyet } \\
\hline & $\mathbf{n}$ & Ortalama \pm SD & Ortanca (IQR) & $\mathbf{P}$ \\
\hline $\begin{array}{l}\text { Yoğun Bakım Ünitesi } \\
\text { Nöroloji* } \\
\text { Anestezi* } \\
\text { Genel cerrahi } \\
\text { Beyin cerrahi } \\
\text { Dahiliye* } \\
\text { Kalp damar cerrahi }\end{array}$ & $\begin{array}{l}41 \\
42 \\
33 \\
26 \\
37 \\
11\end{array}$ & $\begin{array}{l}42346.1 \pm 31409.3 \\
38988.9 \pm 64217.4 \\
27185.9 \pm 54872.1 \\
24982.8 \pm 24623.6 \\
17382.7 \pm 12495.4 \\
16546.0 \pm 23872.8\end{array}$ & $\begin{array}{c}39120.0(18236.0-60079.2) \\
24573.5(15239.9-35863.7) \\
16870.0(6367.5-25288.8) \\
19507.8(14459.5-30599.1) \\
15393.0(10030.5-21249.0) \\
8168.6(4754.9-13792.9)\end{array}$ & $<0.001$ \\
\hline $\begin{array}{l}\text { Infeksiyonlar } \\
\text { Kateter ilişkili kan dolaşımı infeksiyonu } \\
\text { Ventilatör iliş̧ili pnömoni } \\
\text { Üriner sistem infeksiyonu } \\
\text { İntrakranial infeksiyon } \\
\text { Organ boşluk infeksiyonu } \\
\text { Bakteriyemi } \\
\text { Yüzeyel cerrahi alan infeksiyonu } \\
\text { Derin insizyonel cerrahi alan infeksiyonu }\end{array}$ & $\begin{array}{c}82 \\
97 \\
33 \\
8 \\
6 \\
16 \\
30 \\
24\end{array}$ & $\begin{array}{l}42593.7 \pm 75381.6 \\
33162.5 \pm 32638.1 \\
29061.5 \pm 26799.0 \\
21923.4 \pm 12708.0 \\
21494.6 \pm 12630.8 \\
19826.6 \pm 17228.0 \\
16284.2 \pm 12975.4 \\
12438.8 \pm 13230.5\end{array}$ & $\begin{array}{c}20593.5(12140.8-39021.2) \\
26335.0(14653.6-40552.0) \\
21462.9(9957.4-36553.0) \\
17411.0(13983.2-28978.5) \\
23895.2(11633.7-28346.0) \\
10910.5(6068.7-40218.2) \\
12169.8(6603.6-25939.3) \\
6427.0(3571.7-16255.5)\end{array}$ & $<0.001$ \\
\hline $\begin{array}{l}\text { Patojenler } \\
\text { Acinetobacter spp.* } \\
\text { P. aeruginosa } \\
\text { Klebsiella spp. } \\
\text { Enterobacter cloacae } \\
\text { E. coli* } \\
\text { Citrobacter spp. } \\
\text { Proteus spp. }\end{array}$ & $\begin{array}{c}148 \\
18 \\
66 \\
8 \\
51 \\
2 \\
3\end{array}$ & $\begin{array}{c}38911.0 \pm 60421.6 \\
30901.6 \pm 24086.7 \\
27051.3 \pm 26552.0 \\
22083.9 \pm 21575.5 \\
14055.7 \pm 11158.0 \\
13409.0 \pm 8707.3 \\
18774.9 \pm 30187.7\end{array}$ & $\begin{array}{c}23077.0(14509.8-39398.5) \\
29343.5(9038.6-42092.0) \\
19691.7(8656.3-36097.2) \\
18047.0(7321.4-24394.5) \\
11440.3(6011.0-19158.4) \\
-- \\
--\end{array}$ & $<0.001$ \\
\hline $\begin{array}{l}\text { Çoklu ilaç Direnci } \\
\text { Evet } \\
\text { Hayır }\end{array}$ & $\begin{array}{c}150 \\
40\end{array}$ & $\begin{array}{l}32954.4 \pm 50124.2 \\
20638.2 \pm 19512.3\end{array}$ & $\begin{array}{c}20113.0(11750.4-36935.5) \\
15393.0(6359.9-27554.0)\end{array}$ & 0.015 \\
\hline
\end{tabular}

spektrumlu beta laktamaz üreten E. coli, Klebsiella türleri, coklu ilaç direncli Pseudomonas aeruginosa ve karpenem dirençli Acinetobacter türlerini coklu ilaç direnc kapsamında değerlendirmektedir ${ }^{[16]}$. Ne yazık ki bu etkenlere bağlı olușan infeksiyonların tedavisi için yeni kușak antibiyotikler geliștirilmemektedir. Yeterli antimikrobiyal seceneklerin olmadığı CiD olan gram-negatif bakterilerin neden olduğu infeksiyonların sıklı̆ğ giderek artmaktadır ${ }^{[17]}$.

Coklu ilaç dirençli gram-negatif bakteri infeksiyonlarında coğunlukla kombine ve ikinci basamak tedavilere ihtiyac duyulmaktadır. $\mathrm{Bu}$ da hastalarda yan etki ve komplikasyon gelișme sıklığında artmaya neden olmaktadır. Direncli sușlara karșı alınan ek izolasyon önlemleri personel is yükünü artırmakta ve hastaların hastanede kalıs sürelerinin uzamasına ve tedavi masraflarının artmasına neden olmaktadır ${ }^{[18]}$. Bu calıșma hastanemizde
YBÜ'lerdeki CíD oranını değerlendiren ve maliyet analizinin yapıldığı bir çalıșmadır.

Yoğun bakım ünitelerinde CíD olan gram-negatif bakteri görülme sıklığı farklllık göstermektedir. Hindistan'da yapilan bir çalıșmada \%58 olarak, Nepal'de ise 147 etkenden 128'inin CiD olan gram-negatif bakterilerden oluștuğu bildirilmiștir ${ }^{[19,20]}$. Ülkemizde YBÜ'lerdeki hastaların prospektif olarak değerlendirildiği bir çalıșmada 100 etkenden 66's1 CiD olan mikroorganizmalar olarak rapor edilmiștir ${ }^{[21]}$. Calıșmamızda YBÜ'lerden elde edilen 296 etkenden 241 (\%81.4)'ini CiD olan gram-negatif bakteriler olușturmakta idi. Anestezi, nöroloji, dahiliye ve genel cerrahi yoğun bakım ünitelerinde görülen CiD olan gram-negatif bakteri infeksiyon sıklığı istatiksel olarak anlamlıydı.

Nepal'de yapılan bir calıșmada yoğun bakım ünitelerinde 147 hastada en sk izole edilen CiD 
olan patojenler Acinetobacter spp., K. pneumonia ve Pseudomonas spp. olarak bildirilmiștir ${ }^{[20]}$. Güncel farklı bir calıșmada da Acinetobacter spp., $P$. aeruginosa ve $K$. pneumoniae en sik C CiD olan etkenler arasinda yer almaktadir ${ }^{[22]}$. Kilıc ve arkadașlarının yaptığı çalıșmada en sı CiID olan etkenler $A$. baumannii, $P$. aeruginosa ve K. pneumoniae olarak bildirilmiștir ${ }^{[21]}$. Calıșmamızda yoğun bakım ünitelerinde Acinetobacter spp., Klebsiella spp. ve E. coli infeksiyonlarında ÇID pozitifliğini anlamlı derecede yüksek bulduk. Pseudomonas türlerini çalıșmamızda diğer çalıșmalardan farklı olarak daha az oranda tespit ettik. Yoğun bakım ünitelerindeki ilerlemelere rağmen ÇID olan gram-negatif bakteri infeksiyonlarının nadir olmadiğını calıșmalar sonucunda görmekteyiz. Yaygın antibiyotik kullanımı, artan ilaç direnci ve infeksiyon kontrol önlemlerine uyulmaması YBÜ'lerdeki CCID olan mikroorganizmalarla gelișen infeksiyonların sık görülmesinin nedenleri arasında yer almaktadır ${ }^{[23]}$.

Yoğun bakım ünitelerindeki infeksiyonların değerlendirildiği ülkemizde yapılan çok merkezli nokta prevalans calıșmasında, ventilatör ilișkili pnömoni ve kan dolașımı infeksiyonları YBÜ'lerinde en sık görülen infeksiyonlar arasında yer almaktadır [24]. Yapılan prospektif kohort bir calıșmada C ID olan patojenler sıklikla alt solunum yolu, kan kültuirü, üriner sistem ve cerrahi alan örneklerinden elde edilmiștir ${ }^{[20]}$. Calıșmamızda en sık görülen infeksiyon türleri VIP, kan dolașımı infeksiyonu, üriner sistem infeksiyonu ve yüzeyel cerrahi alan infeksiyonu idi. Ventilatör ilișili pnömoni, kateter ilișkili kan dolașımı infeksiyonu, bakteriyemi ve yüzeyel cerrahi alan infeksiyonlarında görülen ÇID olan mikroorganizma pozitifliğianlamlı olarak daha yüksekti. Yoğun bakım ünitelerinde takip edilen hastaların büyük kısmının entübe ve mekanik ventilasyonda takip edilmesi ayrica tedavi amacıyla kullanılan kateterlerin varlığı bu durumu açıklamaktadır.

Yapilan çalıșmalar sonucunda ÇiD olan gram-negatif bakteri infeksiyonları hastaların hastanede kalıs sürelerini uzatmaktadır ${ }^{[20,25]}$. Calıșmamızda CíD'i olan ve olmayan hastalardaki yatıs süresi medyan değerleri benzerdi. YBÜ'lerinde takip edilen hastalarda eșlik eden komorbid hastalikları ve yüksek oranda yapilan invaziv girisimler CiID olan gram-negatif bakteri infeksiyon sıklığını $\operatorname{artırmaktadır}^{[26]}$. Bu nedenle hastaların hastanede kalıs sürelerini sadece etkenin CíD olma durumunun değil mevcut komorbid hastalıkları, takipleri sırasında uygulanan invaziv girișimler ve gelișen komplikasyonların da etkilediğini düșunmekteyiz. Calıșmamızda hastalara ait bu özellikler değerlendirilmediğinden yatıs süresine etki eden diğer faktörleri tespit edemedik.

Bazı çalıșmalarda ÇID ile mortalite arasında anlamlı bir ilișki bulunurken ${ }^{[20]}$ bazı calıșmalarda ise CiD olan gram-negatif bakterilerle mortalite arasında anlamlı ilișki bulunamamıștır ${ }^{[12,27]}$. Calıșmamızda CíD olan ve olmayan hastalar arasındaki mortalite dağılımları benzerdi. Calıșmalarda farklı sonuçlar olmasının nedeni, farklı coğrafik bölgelerdeki bakterilerin virülanslarındaki değișiklikten kaynaklanabilir. Ayrıca YBÜ'lerde tanı ya da tedavi amaçı yapilan invaziv girisimler de mortalite ile ilișkili olabilmektedir ${ }^{[25]}$.

Kan kültuiründe gram-negatif bakteri üremesi olan hastalarda yapilan maliyet calısmasında, ÇID olan gram-negatif bakteri (E. coli, K. pneumoniae, Enterobacter spp.) infeksiyonlarında maliyetin daha yüksek olduğu bildirilmiștir ${ }^{[26]}$. Karbapenem dirençi gram-negatif bakteri infeksiyonu olan hastaların karbapenem direnci olmayan hastalarla karșlaștırıldığı bir çalıșmada da karbapenem dirençli hasta grubunda hastanede yatıs süresinin daha uzun olduğu, toplam hastane masraflarının ve antibiyotik maliyetinin fazla olduğu bulunmuștur ${ }^{[28]}$. Bașka bir calıșmada da genișlemiș spektrumlu beta laktamaz üreten Enterobacteriaceae'lar ve CiD olan $P$. aeruginosa infeksiyonlarının artmıs hastane maliyeti ile ilișkili olduğu görülmüștürr ${ }^{[8]}$.

Calıșmamızda CíD olma ve infeksiyon türlerine göre maliyet analizi yapıldığında derin insizyonel cerrahi alan infeksiyonu olanlar ile üriner sistem infeksiyonu ve kateter ilișkili kan dolașımı infeksiyonu olanların toplam maliyet dağılımları arasında anlamlı düzeyde fark olduğunu tespit ettik. Yoğun bakım hastalarının infeksiyonlarından izole edilen patojenlere göre toplam maliyetler değerlendirildiğinde Acinetobacter spp. infeksiyonlarında toplam maliyet ortalaması en yüksek idi. E. coli infeksiyonu bulunanlar ile Klebsiella spp. ve Acinetobacter spp. infeksiyonu bulunan hastaların maliyet dağılımlarında anlamlı düzeyde farklılı vardı. İzole edilen patojenlerde ÇID olmasına 
göre maliyet durumunu incelediğimizde ise CíD bulunan grupta toplam maliyet ortalamasının CiD bulunmayan gruba göre anlamlı düzeyde yüksek olduğunu tespit ettik.

Hastane maliyetlerinin artmasinin nedenleri CiD olan etkenlerle gelișen infeksiyonların tedavisinde kullanılan pahalı antibiyotikler, eșlik eden hastalıklar, yoğun bakım ünitesinin farklılığı ve hastanedeki kalıs sürelerinin uzamasından kaynaklanabilir. Hastaların takiplerinin yapıldığı YBÜ'lere göre maliyet dağılımlarına bakıldığında dahiliye yoğun bakım hastalarının maliyetlerinin anestezi ve nöroloji yoğun bakımdaki hastalarından anlaml düzeyde daha düșük olduğu görüldü. Anestezi ve nöroloji yoğun bakımda takip edilen hastaların eșlik eden klinik durumlarının ciddiyeti ve komorbid hastalıkları yatıs sürelerini uzatmakta bu da maliyet artıșı ile sonuçlanmaktadır.

\section{Çalıșmanın Kısıtlılıkları}

$\mathrm{Bu}$ çalıșmanın ceșitli kısıtlılıkları vardır. Yatan hastaların maliyetleri ilk kan kültürü pozitifliğinden itibaren değil, hastanede yatıs süresi boyunca olan maliyet seklindedir. Ayrıca hastalarda yoğun bakım ünitesinde izlendikleri süre boyunca sadece doğrudan tıbbi maliyetler değerlendirilmiș ve dolaylı maliyetlere yer verilmemiștir. Calıșmanın diğer kısıtlılığı yatıș sürelerinin uzamasına ve maliyet artıșına neden olan komorbid durumlarının değerlendirilmemesidir.

\section{SONUÇ}

Coklu ilaç dirençli gram-negatif bakteri infeksiyonları klinik ve ekonomik olarak oldukça önemlidir. Calıșmamı, YBÜ'inde ÇID olan gram-negatif bakteri infeksiyonlarının yüksek insidansını göstermektedir. Bu infeksiyonlar antibiyotik maliyetini, toplam maliyetleri ve YBÜ'de kalıs süresini artırmaktadır. Calıșmamız ÇID olan etkenlerdeki endise verici durumu yansitmaktadır. Korunmada CiD olan etkenlerle infekte hastalara uygun infeksiyon kontrol önlemlerinin uygulanması, düzenli cevre temizliği, el hijyeni uyumunun artırılması, invaziv girisimlerin en aza indirilmesi ve invaziv girișimleri olan hastaların her gün yakın takip edilmesi önerilmektedir. Her hastanenin CíD olan etkenlerle gelișen infeksiyonlar için yönetim algoritmalarının olması infeksiyon kontrolünü kolaylaștırarak hastane maliyetlerinin azaltılmasına katkıda bulunabilir.

\section{ETIK KURUL ONAYI}

Calıșma için Atatürk Üniversitesi Tıp Fakültesi Klinik Araștırmalar Etik Kurulundan onay alındı (Karar no: 01-51 Tarih: 16.01.2020).

\section{ÇIKAR ÇATIŞMASI}

Yazarlar bu makale ile ilgili herhangi bir cıkar çatıșması bildirmemișlerdir.

\section{YAZAR KATKISI}

Anafikir/Planlama: HA, SY, FKC

Analiz/Yorum: HA, SY

Veri Sağlama: HA, FKC

Yazım: HA, SY

Gözden Geçirme ve Düzeltme: HA, SY, FKC

\section{KAYNAKLAR}

1. Fridkin SK, Welbel SF, Weinstein RA. Magnitude and prevention of nosocomial infections in the intensive care unit. Infect Dis Clin North Am 1997;11:479.

2. Vincent JL, Rello J, Marshall J, Silva E, Anzueto A, Martin CD, et al. International study of the prevalence and outcomes of infection in intensive care units. JAMA 2009;302:2323.

3. Hynes-Gay P, Lalla P, Leo M, Merrill-Bell A, Nicholson M, Villaruel E. Understanding sepsis: from SIRS to septic shock. Dynamics 2002;13:17-20.

4. Kaye KS, Marchaim D, Smialowicz C, Bentley L. Suction regulators: a potential vector for hospital-acquired pathogens. Infect Control Hosp Epidemiol 2010;31:772.

5. National Nosocomial Infections Surveillance (NNIS) system report, data summary from January 1992-April 2000, issued June 2000. Am J Infect Control 2000;28:429.

6. Hidron Al, Edwards JR, Patel J, Horan TC, Sievert DM, Pollock DA, et al. NHSN annual update: antimicrobial-resistant pathogens associated with healthcare-associated infections: annual summary of data reported to the National Healthcare Safety Network at the Centers for Disease Control and Prevention, 2006-2007. Infect Control Hosp Epidemiol 2008;29:996.

7. Schwaber MJ, Carmeli Y. The effect of antimicrobial resistance on patient outcomes: importance of proper evaluation of appropriate therapy. Crit Care 2009;13:106.

8. Giske CG, Monnet DL, Cars O, Carmeli Y. Clinical and economic impact of common multidrug-resistant gram-negative bacilli. Antimicrob Agents Chemother 2008;52:813.

9. Rosenthal VD, Maki DG, Salomao R, Moreno CA, Mehta $Y$, Higuera $F$, et al. Device-associated nosocomial infections in 55 intensive care units of 8 developing countries. Ann Intern Med 2006;145:582.

10. Cosgrove SE. The relationship between antimicrobial resistance and patient outcomes: mortality, length of hospital stay, and health care costs. Clin Infect Dis 2006;42:82-9. 
11. Ben-David D, Kordevani R, Keller N, Tal I, Marzel A, GalMor $\mathrm{O}$, et al. Outcome of carbapenem resistant Klebsiella pneumoniae bloodstream infections. Clin Microbiol Infect 2012;18(1):54-60.

12. Blot S, Vandewoude K, De Bacquer D, Colardyn F. Nosocomial bacteremia caused by antibiotic-resistant gram-negative bacteria in critically ill patients: clinical outcome and length of hospitalization. Clin Infect Dis 2002;34(12):1600-6.

13. Menashe G, Borer A, Yagupsky P, Peled N, Gilad J, Fraser $D$, et al. Clinical significance and impact on mortality of ESBL-producing gram-negative isolates in nosocomial bacteremia. Scand J Infect Dis 2001;33(3):188-93.

14. Centers for Disease Control and Prevention/National Healthcare Safety Network. CDC/NHSN Surveillance Definitions for Specific Types of Infections. January 2017.

15. Magiorakos $A P$, Srinivasan A, Carey RB, Carmeli $Y$, Falagas $M E$, Giske CG, et al. Multidrug-resistant, extensively drugresistant and pandrug-resistant bacteria: an international expert proposal for interim standard definitions for acquired resistance. Clin Microbiol Infect 2012;18(3):268-81

16. Talbot GH, Bradley J, Edwards JE, Gilbert D, Scheld M, Bartlett JG. Bad bugs need drugs: an update on the development pipeline from the Antimicrobial Availability Task Force of the Infectious Diseases Society of America. Clin Infect Dis 2006;42:657-668.

17. Falagas, ME, Bliziotis IA, Kasiakou SK, Samonis G, Athanassopoulou P, Michalopoulos A. Outcome of infections due to pandrugresistant (PDR) gram-negative bacteria. BMC Infect Dis 2005;5:24.

18. Oliva A, Giacobbe DR, Di Luca M, Miller NS. New Insights into Infections due to multidrug resistant gram negative bacteria: The Interplay between Lab and Clinic. Biomed Res Int 2018;2018: 8905874.

19. Subhedar V, Jain SK. Gram negative super bugs: a new generation of ICU infections, an emerging challenge for health care settings. Am J Microbiol Res 2016;4:47-50.

20. Siwakoti S, Subedi A, Sharma A, Baral R, Bhattarai NR, Khanal $B$. Incidence and outcomes of multidrug-resistant gram-negative bacteria infections in intensive care unit from Nepal- a prospective cohort study. Antimicrob Resist Infect Control 2018;26(7):114.

21. Kılı̧ $A U$, Ünivar GK, Cevahir F, Alp E. Economic Burden of Multidrug-resistant Gram-Negative Infections in a Developing Country. Erciyes Med J 2019;41(3):312-5.
22. Ibrahim ME. High antimicrobial resistantrates among Gram-negative pathogens in intensive care units. A retrospective study at a tertiary care hospital in South west Saudi Arabia. Saudi Med J 2018;39(10):1035-43.

23. Parajuli NP, Acharya SP, Mishra SK, Parajuli K, Rijal PB, Pokhrel BM. High burden of antimicrobial resistance among gram-negative bacteria causing healthcare associated infections in a critical care unit of Nepal. Antimicrob Resist Infect Control 2017;6:67.

24. Araç E, Kaya Ş, Parlak E, Büyüktuna SA, Baran Ai, Akgül F, et al. yoğun bakım ünitelerindeki infeksiyonların değerlendirilmesi: çok merkezli nokta prevalans çalışması. Mikrobiyol Bul 2019;53(4):364-73.

25. Thaden JT, Li Y, Ruffin F, Maskarinec SA, Hill-Rorie JM, Wanda $L C$, et al. Increased costs associated with bloodstream infections caused by multidrug-resistant gram-negative bacteria are due primarily to patients with hospital-acquired infections. Antimicrob Agents Chemother 2017;23;61(3).

26. MacVane SH. Antimicrobial resistance in the intensive care unit: a focus on gram-negative bacterial infections. I Intensive Care Med 2017;32:25-37.

27. Menashe G, Borer A, Yagupsky P, Peled N, Gilad J, Fraser $D$, et al. Clinical significance and impact on mortality of ESBL-producing gram-negative isolates in nosocomial bacteremia. Scand I Infect Dis 2001;33(3):188-93.

28. Vargas Alzate CA, Higuita Gutierrez LF, Lopez Lopez L, Cienfuegos Gallet AV, Jimenez Quiceno JN. High excess costs of infections caused by carbapenem-resistant Gram-negative bacilli in an endemic region. Int J Antimicrob Agents 2018;51(4):601-7.

\section{Yazıșma Adresi/Address for Correspondence}

Dr. Öğr. Üyesi Handan ALAY

Atatürk Üniversitesi Tıp Fakültesi, İnfeksiyon Hastalıkları ve

Klinik Mikrobiyoloji Anabilim Dal, Erzurum-Türkiye

E-posta: alayhandan@gmail.com 